\title{
Molecular Characterization of Community-Associated Methicillin-Resistant Staphylococcus aureus in Iranian Burn Patients
}

\author{
Samira Tajik $^{1}$, Shahin Najar-Peerayeh ${ }^{1 *}$ (iD), Bita Bakhshi1 ${ }^{(\mathbb{D})}$, Reza Golmohammadi ${ }^{2}$ (D) \\ 1. Department of Bacteriology, Faculty of Medical Sciences, Tarbiat Modares University, Tehran, Iran \\ 2. Molecular Biology Research Center, Systems Biology and Poisonings Institute, Baqiyatallah University of Medical Sciences, Tehran, Iran
}

\begin{tabular}{|c|c|}
\hline KEYWORDS & ABSTRACT \\
\hline $\begin{array}{l}\text { Burn } \\
\text { Patients } \\
\text { MRSA, } \\
\text { SCCmec }\end{array}$ & $\begin{array}{l}\text { Background \& Objective: Methicillin-resistant Staphylococcus aureus (MRSA) is } \\
\text { reported as one of the important bacterial causes of burn wound infections. This study } \\
\text { was carried out to investigate molecular characterization of community-associated } \\
\text { MRSA (CA-MRSA) isolated from Iranian burn patients. }\end{array}$ \\
\hline Scan to discover online & $\begin{array}{l}\text { Methods: A total of } 31 \text { isolates of } S \text {. aureus were collected from the Motahari Burns } \\
\text { Hospital (Tehran, Iran) in } 2016 \text {. All isolates were collected from outpatients and inpatients } \\
\text { within } 48 \text { hours of admission. The } m e c A, p v l \text {, tsst- } 1 \text {, hla- } \alpha \text {, and } p s m \alpha \text { genes detecting, } \\
\text { SCCmec, agr and PFGE typing were done. }\end{array}$ \\
\hline (1) & $\begin{array}{l}\text { Results: A total of } 13(41.9 \%) \text { isolates were cefoxitin-resistant and mecA-positive, } \\
\text { which were considered as MRSA. The SCCmec typing MRSA strains revealed type II }\end{array}$ \\
\hline $\begin{array}{l}\text { Main Subjects: } \\
\text { Microbiology }\end{array}$ & $\begin{array}{l}\text { in } 1(7.7 \%) \text {, type III in } 9(69.2 \%) \text {, and other types in } 3 \text { isolates }(23.7 \%) \text { cases. The } a g r \\
\text { typing of all } 31 \text { isolates showed that } 14(45.2 \%), 1(3.2 \%), 6(19.4 \%) \text {, and } 10(32.3 \%)\end{array}$ \\
\hline $\begin{array}{l}\text { Received } 22 \text { Nov 2018; } \\
\text { Accepted } 12 \text { Jul 2019; } \\
\text { Published Online 22 Sep 2019; }\end{array}$ & $\begin{array}{l}\text { strains belonged to } a g r \text { groups } 1,3,4 \text {, and unknown type, respectively. The } p v l \text {, tsst-1, } \\
\text { hla- } \alpha \text {, and } p s m \alpha \text { genes were positive in } 3(9.7 \%), 4(12.9 \%), 21(67.7 \%) \text {, and } 31(100 \%) \\
\text { isolates, respectively. Considering the cut-off values of } \geq 50 \%, 3 \text { groups of related } \\
\text { isolates (cluster A1, B1, and C1) in PFGE study were observed. }\end{array}$ \\
\hline $\begin{array}{l}\text { doi 10.30699/ijp.2019.94189.1917 } \\
\text { PMCID: }\end{array}$ & $\begin{array}{l}\text { Conclusion: The MRSA strains of this study were initially isolated as Community- } \\
\text { associated S. aureus (CA-MRSA); however molecular characterization showed that a } \\
\text { significant proportion of them had hospital-associated MRSA (HA-MRSA) features. }\end{array}$ \\
\hline PMID: & Therefore, it is likely that the HA-MRSA strains are spread among the community. \\
\hline
\end{tabular}

Corresponding Information:

Shahin Najar-Peerayeh, Department of Bacteriology, Faculty of Medical Sciences, Tarbiat Modares University, Tehran, Iran Email: najarp_s@modares.ac.ir

Copyright ( $)$ 2019. This is an open-access article distributed under the terms of the Creative Commons Attribution- 4.0 International License which permits Share, copy and redistribution of the material in any medium or format or adapt, remix, transform, and build upon the material for any purpose, even commercially.

\section{Introduction}

Due to the skin damaged and weakened innate immunity, burn patients become susceptible to various infections $(1,2)$, among which bacterial infections are the main problems in hospitalized burn patients $(3,4)$.

Staphylococcus aureus is one of the most common bacteria isolated from burn infections (5). Methicillinresistant $S$. aureus (MRSA) including hospitalassociated MRSA (HA-MRSA) $(3,6)$ and communityassociated MRSA (CA-MRSA) (7) are reported as the important bacterial causes of burn wound infections. The centers for disease control (CDC) defined a CA-MRSA infection as any MRSA infection diagnosed for an outpatient or within 48 hours of hospitalization if the patient lacks such healthcare-associated MRSA risk factors as dialysis or use of invasive medical devices, surgery, and residence in a long-term care facility or hospitalization during the previous year; all other MRSA infections were considered to be HA-MRSA (8-10).
Cefoxitin is a potential inducer of the mecA regulatory system and is used for screening MRSA strains (11). Staphylococcal cassette chromosome mec (SCCmec) element of MRSA strains carry mecA gene that mediates resistance to methicillin $(10,12)$. HAMRSA strains carry large SCCmec types II and III, which are responsible for resistance to other antibiotics. However, SCCmec types IV and V elements are found in CA-MRSA strains $(10,13)$.

It should be noted that there are several problems in terms of using CA-MRSA and HA-MRSA. First, both strains can be circulated in the community; second, it is possible that CA-MRSA strains are gradually converted to nosocomial pathogens $(10,14)$.

The pathogenicity of $S$. aureus is associated with various virulence factors genes including accessory gene regulator (agr) system, panton-valentine leukocidin $(p v l)$, toxic shock syndrome toxin (tsst), $\alpha$-hemolysin (hla), and alpha-type phenol soluble modulins (psma). 
These virulence factors can make extensive infection and severe damage $(7,12,15,16)$. The agr regulatory system has a crucial role in the development of skin infection cases by most CA-MRSA USA300 strains (17). The PVL toxin can be found in both MSSA and MRSA strains (18) but typically is associated with CAMRSA strains (7). TSST-1 is a superantigen that is absorbed from cutaneous infections and it localizes the kidneys (19). It is reported that the pore-forming $\alpha$ hemolysin of $S$. aureus plays a key role in soft tissue infection (20). The psma may play a role in biofilms development and lysis of human cell types such as leukocytes and erythrocytes; also, it stimulates inflammation response (21).

Phenotypic and genotypic characterization of CAMRSA and HA-MRSA can be helpful in the treatment, infection control, and prevention of the spread of antibiotic-resistant bacterial strains $(1,22,23)$. This study was carried out to investigate molecular characterization of CA-MRSA isolated from Iranian burn outpatients and hospitalized patients within 48 hours of admission.

\section{Materials and Methods \\ Bacterial Isolates}

A total of 31 isolates of $S$. aureus were collected from Shahid Motahari Burns Hospital (Tehran, Iran) in the time period of May to October 2016. All isolates were collected from outpatients and inpatients within 48 hours of admission. Bacterial morphology study and biochemical tests including catalase, tube and slide coagulase, DNase, and mannitol-fermenting were done to identify $S$. aureus. After identification, all strains were preserved in trypticase soy broth medium containing $15 \%$ glycerol at $-70^{\circ} \mathrm{C}$.

\section{Antimicrobial Susceptibility Testing}

Antimicrobial susceptibility testing was done by disk diffusion method according to the clinical and laboratory standards institute (CLSI) 2015 guidelines. Antibiotic discs containing cefoxitin $(30 \mu \mathrm{g})$, gentamicin $(10 \mu \mathrm{g})$, erythromycin $(15 \mu \mathrm{g})$, tetracycline $(30 \mu \mathrm{g})$, rifampin $(5$ $\mu \mathrm{g})$, clindamycin $(2 \mu \mathrm{g})$, ciprofloxacin $(5 \mu \mathrm{g})$, trimethoprim-sulfamethoxazole $(1.25 / 23.75 \mu \mathrm{g})$, and linezolid $(30 \mu \mathrm{g})$ (MAST UK) were used. S. aureus ATCC 25923 was used as a control strain.

\section{Molecular Detection and Typing \\ DNA Extraction}

Four to five fresh colonies of bacteria were suspended in $400 \mu \mathrm{L}$ of lysis solution buffer containing lysostaphin $(200 \mu \mathrm{g} / \mathrm{mL})$ (Sigma-Aldrich Co, Germany). Then, DNA was extracted by phenol/chloroform /isoamyl alcohol (Merck Co).

\section{PCR Amplification}

The mecA was used as target gene for the detection of MRSA strains (24). The primers described by Zhang et al. (24) and Shopsin et al. (25) were used for SCCmec typing and agr typing, respectively. RN6390, RN6607, RN8465, and RN4550 strains were used as positive control for $a g r$ typing. The $p v l$, tsst-1, hla- $\alpha$ (26), and psm $\alpha$ (27) genes were used as target gene for virulotyping. The list of primers sequences of this study, target genes, and the length of PCR products are presented in Table 1.

Table1. The list of primers sequences for mecA, pvl, tsst-1, hla- $\alpha$, and $p s m \alpha$ genes detection, SCCmec and agr typing and PCR products length

\begin{tabular}{|c|c|c|c|c|}
\hline & Primer & Sequence $\left(5^{\prime} \rightarrow 3^{\prime}\right)$ & Size (bp) & Ref \\
\hline $\begin{array}{r}m e c A \\
\text { detection }\end{array}$ & mecA & $\begin{array}{l}\text { F: GTGAAGATATACCAAGTGATT } \\
\text { R: ATGCGCTATAGATTGAAAGGA }\end{array}$ & 146 & (24) \\
\hline \multirow{8}{*}{$\begin{array}{c}\text { SCCmec } \\
\text { typing }\end{array}$} & SCCmec I & $\begin{array}{l}\text { F: GCTTTAAAGAGTGTCGTTACAGG } \\
\text { R: GTTCTCTCATAGTATGACGTCC }\end{array}$ & 613 & \multirow{8}{*}{ (24) } \\
\hline & $\mathrm{SCCmec} \mathrm{II}$ & $\begin{array}{c}\text { F: CGTTGAAGATGATGAAGCG } \\
\text { R: CGAAATCAATGGTTAATGGACC }\end{array}$ & 398 & \\
\hline & SCCmec III & $\begin{array}{c}\text { F: CCATATTGTGTACGATGCG } \\
\text { R: CCTTAGTTGTCGTAACAGATCG }\end{array}$ & 280 & \\
\hline & $\begin{array}{l}\text { SCCmec } \\
\text { IVa }\end{array}$ & $\begin{array}{c}\text { F: GCCTTATTCGAAGAAACCG } \\
\text { R: CTACTCTTCTGAAAAGCGTCG }\end{array}$ & 776 & \\
\hline & $\begin{array}{l}\mathrm{SCCmec} \\
\mathrm{IVb}\end{array}$ & $\begin{array}{l}\text { F: TCTGGAATTACTTCAGCTGC } \\
\text { R: AAACAATATTGCTCTCCCTC }\end{array}$ & 493 & \\
\hline & $\begin{array}{l}\text { SCCmec } \\
\text { IVc }\end{array}$ & $\begin{array}{l}\text { F: ACAATATTTGTATTATCGGAGAGC } \\
\text { R: TTGGTATGAGGTATTGCTGG }\end{array}$ & 200 & \\
\hline & $\begin{array}{l}\text { SCCmec } \\
\text { IVd }\end{array}$ & $\begin{array}{c}\text { F: CTCAAAATACGGACCCCAATACA } \\
\text { R: TGCTCCAGTAATTGCTAAAG }\end{array}$ & 881 & \\
\hline & SCCmec V & $\begin{array}{l}\text { F: GAACATTGTTACTTAAATGAGCG } \\
\text { R: TGAAAGTTGTACCCTTGACACC }\end{array}$ & 325 & \\
\hline \multirow{6}{*}{ agr typing } & panF & ATGCACATGGTGCACATGC & - & \multirow{5}{*}{$(\mathbf{2 5})$} \\
\hline & $\operatorname{agr} \mathrm{I}-\mathrm{R}$ & GTCACAAGTACTATAAGCTGCGAT & 440 & \\
\hline & $a g r$ II-R & GTATTACTAATTGAAAAGTGCCATAGC & 572 & \\
\hline & agr III-R & CTGTTGAAAAAGTCAACTAAAAGCTC & 406 & \\
\hline & $\operatorname{agr} \mathrm{IV}-\mathrm{R}$ & CGATAATGCCGTAATAC CCG & 588 & \\
\hline & $p v l$ & F: GGAAACATTTATTCTGGCTATAC & 502 & (26) \\
\hline
\end{tabular}




\begin{tabular}{|c|c|c|c|c|}
\hline & Primer & Sequence $\left(5^{\prime} \rightarrow 3^{\prime}\right)$ & Size (bp) & Ref \\
\hline \multirow{4}{*}{$\begin{array}{l}\text { Virulence } \\
\text { genes typing }\end{array}$} & \multicolumn{3}{|c|}{ R: CTGGATTGAAGTTACCTCTGG } & \\
\hline & tsst -1 & $\begin{array}{c}\text { F: TTATCGTAAGCCCTTTGTTG } \\
\text { R: TAAAGGTAGTTCTATTGGAGTAGG }\end{array}$ & 398 & \\
\hline & hla- $\alpha$ & $\begin{array}{l}\text { F: CGGTACTACAGATATTGGAAGC } \\
\text { R: TGGTAATCATCACGAACTCG }\end{array}$ & 744 & \\
\hline & psma & $\begin{array}{l}\text { F: TATCAAAAGCTTAATCGAACAATTC } \\
\text { R: CCCCTTCAAATAAGATGTTCATATC }\end{array}$ & 176 & (27) \\
\hline
\end{tabular}

The final volume of $25 \mathrm{~mL}$ PCR reaction mixture containing reverse and forward primer $(10 \mathrm{pmol})$ (Pishgam Biotech Co, Iran), DNA taq polymerase enzyme (1.5 units), dNTPs (0.02 mM), $\mathrm{MgCl}_{2}(0.1 \mathrm{mM})$, buffer (Fermentase Co, Lithuania), deionized distilled water, and DNA template were used for PCR amplification. The PCR amplification performed in thermo cycler (BIO RAD T100) by following annealing temperatures: $m e c A ; 55^{\circ} \mathrm{C}$, SCCmec typing; $60^{\circ} \mathrm{C}$, agr typing; $50^{\circ} \mathrm{C}$, and virulence genes typing; $50^{\circ} \mathrm{C}$ for $p v l$ and hla- $\alpha$, and $51^{\circ} \mathrm{C}$ for $t$ sst- 1 genes.

\section{Pulsed-field Gel Electrophoresis (PFGE)}

PFGE analysis based on SmaI restriction enzyme (Takara) digestion was carried out using the PulseNet standard protocol on 13 SCCmec-positive S. aureus strains (PulseNet, www.cdc.gov/pulsenet). After optimizing conditions, PFGE was run on $\mathrm{CHEF}$ MAPPER $^{\mathrm{XA}}$ (BIO RAD) device as follows: initial switch $5 \mathrm{~s}$, final switch $40 \mathrm{~s}$, run time $21 \mathrm{~h}$, voltage 200 $(6 \mathrm{v} / \mathrm{cm}) .1 \%$ agarose gel (intron biotechnology) in TBE $0.5 \mathrm{X}$ was used for electrophoresis. According to the PulseNet protocol, Salmonella enterica serotype Braenderup (H9812) was used as a control. After gel staining with ethidium bromide $(10 \mathrm{mg} / \mathrm{mL})$, imaging was performed by UV light gel documentation system (BioDocAnalyze). GelCompar II version 6.6.11 software was used for drawing dendrogram graph and interpretation of results. Cut-off values of $\geq 50 \%$ were considered to define clusters.

\section{Results}

\section{Patients}

A total of 31 non-duplicate $S$. aureus isolates were investigated in this study. All isolates were collected from burn patients within 48 hours of admission. 20 $(64.5 \%)$ of these patients were inpatients and 11 $(35.5 \%)$ outpatients.

\section{Antimicrobial Susceptibility Testing}

Antibiotic susceptibility test results revealed that a total of $13(41.9 \%)$ isolates were resistant to cefoxitin, which were considered as MRSA. All isolates were susceptible to Linezolid. The resistance rates of other antibiotics were as follows: erythromycin $15(48.4 \%)$, tetracycline $11(35.5 \%)$, ciprofloxacin $11(35.5 \%)$, gentamicin $10(32.3 \%)$, clindamycin 9 (29.0\%), rifampin $6(19.4 \%)$, and trimethoprimsulfamethoxazole 4 (12.9\%) (Table 2).

Table2. Antibiotic resistance of MSSA and MRSA isolated from burn patient

\begin{tabular}{cccc}
\hline Antibiotics & MSSA $(\mathbf{n = 1 8})$ & MRSA $(\mathbf{n = 1 3})$ & Total $(\mathbf{n}=\mathbf{3 1})$ \\
\hline cefoxitin & 0 & $13(100 \%)$ & $13(41.9 \%)$ \\
\hline erythromycin & $6(33.3 \%)$ & $9(69.2 \%)$ & $15(48.4 \%)$ \\
\hline tetracycline & $3(16.7 \%)$ & $8(61.5 \%)$ & $11(35.5 \%)$ \\
\hline ciprofloxacin & $2(11.1 \%)$ & $9(69.2 \%)$ & $11(35.5 \%)$ \\
\hline gentamicin & $1(5.5 \%)$ & $9(69.2 \%)$ & $10(32.3 \%)$ \\
\hline clindamycin & $2(11.1 \%)$ & $7(53.8 \%)$ & $9(29.0 \%)$ \\
\hline rifampin & $1(5.5 \%)$ & $5(38.5 \%)$ & $6(19.4 \%)$ \\
\hline $\begin{array}{c}\text { trimethoprim- } \\
\text { sulfamethoxazole }\end{array}$ & 0 & $4(30.8 \%)$ & $4(12.9 \%)$ \\
\hline Linezolid & 0 & 0 & 0 \\
\hline
\end{tabular}

\section{Molecular Detection and Typing}

Molecular studies showed that 13 (41.9\%) isolates were mecA-positive (Table 3 ). The SCCmec typing MRSA strains revealed type II in $1(7.7 \%)$, type III in 9 (69.2\%), and other types in 3 isolates $(23.1 \%)$ (Table 3 ).

The agr typing of all 31 isolates showed that 14 (45.1\%), 1 (3.2\%), $6(19.4 \%)$, and $10(32.3 \%)$ strains belonged to $a g r$ groups $1,3,4$, and unknown type, respectively (Table 3).
The $p v l$, tsst-1, hla- $\alpha$, and psm $\alpha$ genes were positive in $3(9.7 \%), 4(12.9 \%), 21(67.7 \%)$, and $31(100 \%)$, respectively.

All 13 MRSA isolates were studied by PFGE. Considering the cut-off values of $\geq 50 \%, 3$ groups of isolates (cluster A1, B1, and C1) were observed in this study: cluster A1; 3 pulse types, cluster B1; 3 pulse types and cluster $\mathrm{C} 1 ; 2$ pulse types (Figure 1). 
Table 3. The mecA, $p v l$, tsst-1, hla- $\alpha$, and $p s m \alpha$ genes detection, and SCCmec and agr typing result ( $\mathrm{n}=31)$

\begin{tabular}{|c|c|c|c|c|c|c|c|c|c|}
\hline gene & mecA & & Cmec & & $a g r$ & $p v l$ & tsst-1 & hla-a & psma \\
\hline \multirow{4}{*}{ Positive } & \multirow{4}{*}{$13(41.9 \%)$} & type3 & $9(69.2 \%)$ & type 1 & $14(45.1 \%)$ & \multirow{4}{*}{$3(9.7 \%)$} & \multirow{4}{*}{$4(12.9 \%)$} & \multirow{4}{*}{$21(67.7 \%)$} & \multirow{4}{*}{$31(100 \%)$} \\
\hline & & type2 & $1(7.7 \%)$ & type 3 & $1(3.2 \%)$ & & & & \\
\hline & & \multirow{2}{*}{$\begin{array}{c}\text { Not } \\
\text { typeable }\end{array}$} & \multirow[b]{2}{*}{$3(23.1 \%)$} & type 4 & $6(19.4 \%)$ & & & & \\
\hline & & & & $\begin{array}{c}\text { Not } \\
\text { typeable }\end{array}$ & $10(32.3 \%)$ & & & & \\
\hline Negative & $18(58.1 \%)$ & \multicolumn{3}{|c|}{18} & $0(0 \%)$ & $28(90.3)$ & $27(87.1 \%)$ & $10(32.3 \%)$ & $0(0 \%)$ \\
\hline
\end{tabular}

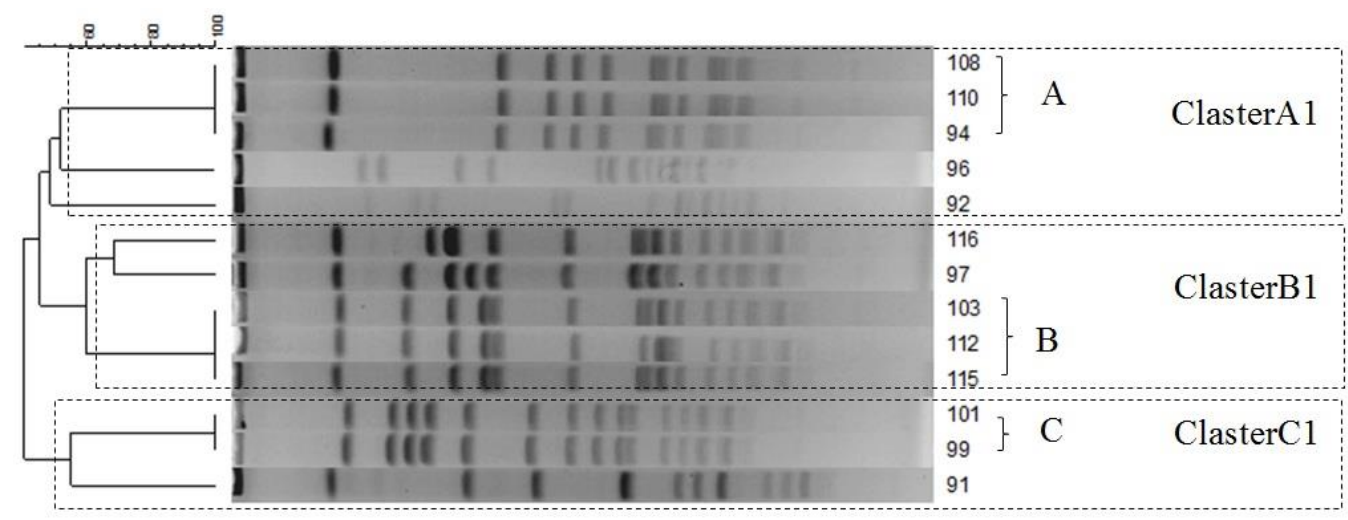

Figure1. PFGE analysis of CA-MRSA in current study

\section{Discussion}

S. aureus is one of the common causes of burn wound infections (5). Drug-resistant strains of this organism such as MRSA can complicate the treatment process $(3,6,7)$. In addition, the strains containing virulence genes such as agr, pvl, tsst-1, hla- $\alpha$, and psm $\alpha$ can make extensive infection and severe damage $(7,15,16,28,29)$.

In current study $41.9 \%$ isolates were mecA-gene positive and cefoxitin-resistant, so were considered as MRSA. Based on the molecular detection of mec gene in different studies, MRSA strains have been reported as $86.4 \%$ (30), $88.6 \%$ (31), $81.2 \%$ (32), and $87.4 \%$ (18) in Iran and $55.3 \%$ in China (3).

According to the antibiotic susceptibility testing of all 31 strains, the highest resistance was related to erythromycin (48.4\%) compared to $58.2 \%$ (2), $77.8 \%$ (30), and $90.6 \%$ (16) in Iran. All the 13 MRSA strains in this study were sensitive to linezolid, which was similar to the findings of the studies conducted by Montazeri (31, 32), and Goudarzi (16) from Iran and Murray (7) from the US.

The SCCmec typing of 13 MRSA strains showed that $9(69.2 \%)$ strains belonged to SCCmec III, that's almost is consistent with some studies in Iran; $56.8 \%$ (2), $47.5 \%$ (33), $70.1 \%$ (15), and $71.7 \%$ (16) did not match the other studies in Iran; 95.7\% (30), China; 95.4\% (16), Brazil; $94.8 \%$ (34). $7.7 \%$ of the these 13 strains belonged to SCCmec II, compared with $10 \%$ (33) and $2.5 \%$ (15) studies in Iran, and (1\%) in Brazil (34). Although 3 (23.1\%) other types were not detected in this study, SCCmec I, IV, and V have been detected in other studies $(2,3,15,16,34)$.
Based on the CDC definition of CA-MRSA and HAMRSA strains (8-10) and according to other studies (10, 13), it seems that most of these SCCmec types belonged to HA-MRSA strains. Since sampling was done within 48 hours after admission, the strains were expected to be CAMRSA. According to a hypothesis, this has been affected by various factors such as having the same source of infection or spread of infected patients with HA-MRSA strains among the community. Since checking the patients' referral records during the last year was not possible in this study, it is possible that most of these strains were HA-MRSA. Furthermore, having high relative resistance to selected antibiotics including clindamycin in most strains also confirms this probability. Eight $(61.5 \%)$ of MRSA strains in this study and $75.5 \%$ in Goudarzi's study (16) were resistant to clindamycin, which indicates these strains had high resistance to other antibiotics. Also, 5 (38.5\%) clindamycin-susceptible strains in this study had a lower resistance to other antibiotics. Therefore, it can be concluded that $8(61.5 \%)$ of these strains correspond to HA-MRSA and 5 (38.5\%) to CA-MRSA.

The PFGE cluster results with cut-off values of $\geq 50 \%$ indicated that MRSA strains in this study, to some extent, had CA-MRSA characteristics. Also, the 3 strains in clusters $\mathrm{A} 1,3$ in $\mathrm{B} 1$, and 2 in $\mathrm{C} 1$ have the same pattern. This similarity suggests that the source of infection has been the same in each cluster.

The PVL toxin typically is associated with CAMRSA strains (7). In the present study, 3 (9.7\%) MRSA strains were $p v l$-positive. In contrast to the study by 
Goudarzi that reported the positive $p v l$ strains belonged to SCCmec type IV (16), in this study 2 of 3 strains belonged to the SCCmec type III. Although all MSSA strains in this study were $p v l$-negative, some other studies in Iran reported that $7.23 \%$ (18), $15.1 \%$ (16), and $33.3 \%$ (18) of MSSA cases were positive.

The agr typing assay of all 31 isolates showed that the highest rate belonged to agr type $1(45.1 \%)$ compared to $84.9 \%$ in Iran (16) and $96.5 \%$ in China (3); meanwhile, the lowest rate belonged to agr type $3(3.2 \%)$ compared to $15.1 \%$ in Iran (16). In this study, $32.3 \%$ strains were not typeable, which might be related to the presence of different mutations, sensitivity, and specificity of primers.

The $t s s t-1$ gene detection showed that $12.9 \%$ of the isolates in this study belonged to MSSA strains, but this gene was not seen in MRSA strains. In contrast to this study, in a different study in Iran $18.9 \%$ of MRSA isolates were $t$ sst-positive which were distributed among SCCmec type III (16).

In the present study, $67.7 \%$ strains were hla-positive compared to another study in Iran which reported 51.8\% (15). Data analysis showed that $32.2 \%$ belonged to MRSA and $35.5 \%$ to MSSA.

Our results showed that $41.9 \%$ of isolates were MRSA, which indicates the presence of antibiotic resistance elements in a significant number of strains and necessity of performing antibiogram before starting treatment. Furthermore, the MRSA strains of this study were initially isolated as CA-MRSA, however molecular characterization showed that a significant proportion of them had HA-MRSA features. Therefore, it is likely that the HA-MRSA strains are spread among the community. Finally, the investigation of virulence factors in this study showed the presence of various toxin genes in isolates that can enhance their ecological niche ability and also make treatment more complicated, especially in burn patients.

\section{Acknowledgements}

The current study was supported by a grant from the Faculty of Medical Sciences, Tarbiat Modares University, Tehran, Iran.

\section{Conflict of Interest}

The authors declared no conflict of interest regarding the publication of this article.

\section{References}

1. Schweizer M, Ward M, Cobb S, McDanel J, Leder L, Wibbenmeyer L, et al. The epidemiology of methicillinresistant Staphylococcus aureus on a burn trauma unit. Infection Control \& Hospital Epidemiology. 2012;33(11):1118-25. [DOI:10.1086/668032] [PMID] [PMCID]

2. Namvar AE, Khodaei F, Bijari A, Lari AR. Detection of integrons and Staphylococcal Cassette Chromosome (SCCmec) types in Staphylococcus aureus isolated from burn and non-burn patients. International journal of health sciences. 2015;9(4):440. [DOI:10.12816/0031234] [PMID] [PMCID]

3. Chen X, Yang H-h, Huangfu Y-c, Wang W-k, Liu Y, Ni Y-x, et al. Molecular epidemiologic analysis of Staphylococcus aureus isolated from four burn centers. Burns. 2012;38(5):738 42. [DOI:10.1016/j.burns.2011.12.023] [PMID]

4. Choopani A, Golmohmmadi R, Rafati H, Imani Fooladi AA. Prevalence of Staphylococcus aureus strains isolated from wound infection and drug sensitivity pattern, Tehran-Iran (2006-07). Journal of Gorgan University of Medical Sciences. 2012;14(3):135-40.

5. Alebachew T, Yismaw G, Derabe A, Sisay Z. Staphylococcus aureus burn wound infection among patients attending Yekatit 12 hospital burn unit, Addis Ababa, Ethiopia. Ethiopian journal of health sciences. 2012;22(3).

6. Kaiser ML, Thompson DJ, Malinoski D, Lane C, Cinat ME. Epidemiology and risk factors for hospital-acquired methicillin-resistant Staphylococcus aureus among burn patients. Journal of Burn Care \& Research. 2011;32(3):42934. [DOI:10.1097/BCR.0b013e318217f92d] [PMID]

7. Murray CK, Holmes RL, Ellis MW, Mende K, Wolf SE, McDougal LK, et al. Twenty-five year epidemiology of invasive methicillin-resistant Staphylococcus aureus (MRSA) isolates recovered at a burn center. Burns. 2009;35(8):1112-7. [DOI:10.1016/i.burns.2009.02.013] [PMID]

8. Gorwitz RJ, Jernigan D, Powers J, Jernigan J. Strategies for clinical management of MRSA in the community: summary of an experts' meeting convened by the Centers for Disease Control and Prevention. 2006. 2009.

9. David MZ, Daum RS. Community-associated methicillinresistant Staphylococcus aureus: epidemiology and clinical consequences of an emerging epidemic. Clinical microbiology reviews. 2010;23(3):616-87. [DOI:10.1128/CMR.00081-09] [PMID] [PMCID]

10. David MZ, Glikman D, Crawford SE, Peng J, King KJ, Hostetler MA, et al. What is community-associated methicillin-resistant Staphylococcus aureus? Journal of Infectious Diseases. 2008;197(9):1235-43. [DOI:10.
[DI 1086/533502] [PMID]

11. Anand K, Agrawal P, Kumar S, Kapila K. Comparison of cefoxitin disc diffusion test, oxacillin screen agar, and PCR for mecA gene for detection of MRSA. Indian journal of medical microbiology. 2009;27(1):27.

12. Ghasemian A, Peerayeh SN, Bakhshi B, Mirzaee M. Detection of accessory gene regulator groups genes and cassette chromosome mec types among Staphylococcus aureus isolated from intensive care unit patients. Asian Pacific journal of tropical disease. 2015;5(2):153-7. [DOI:10.1016/S22221808(14)60643-5]

13. Ito T, Ma XX, Takeuchi F, Okuma K, Yuzawa H, Hiramatsu K. Novel type V staphylococcal cassette chromosome mec driven by a novel cassette chromosome recombinase, ccrC. Antimicrobial Agents and Chemotherapy. 2004;48(7):2637-51. [DOI:10.1128/AAC.48.7.2637-2651.2004] [PMID] [PMCID]

14. Huang H, Flynn NM, King JH, Monchaud C, Morita M, Cohen SH. Comparisons of community-associated methicillin-resistant Staphylococcus aureus (MRSA) and hospital-associated MSRA infections in Sacramento, California. Journal of Clinical Microbiology. 2006;44(7):2423-7. [DOI:10.1128/JCM.0025406] [PMID] [PMCID]

15. Motallebi M, Jabalameli F, Asadollahi K, Taherikalani M, Emaneini M. Spreading of genes encoding enterotoxins, haemolysins, adhesin and biofilm among methicillin resistant Staphylococcus aureus strains with staphylococcal cassette chromosome mec type IIIA isolated from burn patients. 
Microbial pathogenesis. 2016;97:34-7. [DOI:10.1016/ j.micpath.2016.05.017] [PMID]

16. Goudarzi M, Bahramian M, Tabrizi MS, Udo EE, Figueiredo AMS, Fazeli M, et al. Genetic diversity of methicillin resistant Staphylococcus aureus strains isolated from burn patients in Iran: ST239-SCCmec III/t037 emerges as the major clone. Microbial Pathogenesis. 2017;105:1-7. [DOI:10.1016/ j.micpath.2017.02.004] [PMID]

17. Cheung GY, Wang R, Khan BA, Sturdevant DE, Otto M. Role of the accessory gene regulator agr in community-associated methicillin-resistant Staphylococcus aureus pathogenesis. Infection and immunity. 2011;79(5):1927-35. [DOI:10.1128/IAI.00046-11] [PMID] [PMCID]

18. Khosravi AD, Hoveizavi H, Farshadzadeh Z. The prevalence of genes encoding leukocidins in Staphylococcus aureus strains resistant and sensitive to methicillin isolated from burn patients in Taleghani Hospital, Ahvaz, Iran. Burns. 2012;38(2):247-51. [DOI:10.1016/j.burns.2011.08.002] [PMID]

19. Mino MJ, Ortiz RT, Randad P, Moffatt LT, Jordan MH, Shupp JW. Localization of Superantigen Virulence Factors in Kidney Tissue of Animals With Staphylococcus aureus-Infected Burn Wounds. Journal of Burn Care \& Research. 2013;34(1):14250. [DOI:10.1097/BCR.0b013e31827778e3] [PMID]

20. Adhikari RP, Thompson CD, Aman MJ, Lee JC. Protective efficacy of a novel alpha hemolysin subunit vaccine (AT62) against Staphylococcus aureus skin and soft tissue infections. Vaccine. 2016;34(50):6402-7. j.vaccine.2016.09.061] [PMID] [PMCID]

21. Cheung GY, Joo H-S, Chatterjee SS, Otto M. Phenol-soluble modulins-critical determinants of staphylococcal virulence. FEMS microbiology reviews. 2014;38(4):698-719. [DOI:10.1111/1574-6976.12057] [PMID] [PMCID]

22. Mirzaee M, Najar-Peerayeh S, Behmanesh M, Moghadam MF. Relationship between adhesin genes and biofilm formation in vancomycin-intermediate Staphylococcus aureus clinical isolates. Current microbiology. 2015;70(5):665-70. [DOI:10.1007/s00284-014-0771-9] [PMID]

23. Najar-Peerayeh S, Mirzaee M, Behmanesh M. Molecular characterization of vancomycin-intermediate Staphylococcus aureus isolates from Tehran. Asian Pacific Journal of Tropical \begin{tabular}{l} 
Disease. 2016;6(9):726-31. [DOI:10.1016/S2222- \\
\hline
\end{tabular} 1808(16)61118-0]

24. Zhang K, McClure J-A, Elsayed S, Louie T, Conly JM. Novel multiplex PCR assay for characterization and concomitant subtyping of staphylococcal cassette chromosome mec types I to $\mathrm{V}$ in methicillin-resistant Staphylococcus aureus. Journal of clinical microbiology. 2005;43(10):5026-33. [DOI:10.1128/ JCM.43.10.5026-5033.2005] [PMID] [PMCID]

25. Shopsin B, Mathema B, Alcabes P, Said-Salim B, Lina G, Matsuka A, et al. Prevalence of agr specificity groups among
Staphylococcus aureus strains colonizing children and their guardians. Journal of clinical microbiology. 2003;41(1):456-9. [DOI:10.1128/JCM.41.1.456-459.2003] [PMID] [PMCID]

26. Havaei SA, Azimian A, Fazeli H, Naderi M, Ghazvini K, Samiee SM, et al. Genetic characterization of methicillin resistant and sensitive, vancomycin intermediate Staphylococcus aureus strains isolated from different Iranian Hospitals. ISRN microbiology. 2012;2012. [DOI:10.5402/2 012/215275] [PMID] [PMCID]

27. Li M, Cheung GY, Hu J, Wang D, Joo H-S, DeLeo FR, et al. Comparative analysis of virulence and toxin expression of global community-associated methicillin-resistant Staphylococcus aureus strains. Journal of Infectious Diseases. 2010;202(12):1866-76. [DOI:10.1086/657419] [PMID] [PMCID]

28. Kennedy AD, DeLeo FR. Epidemiology and virulence of community-associated MRSA. Clinical Microbiology Newsletter. 2009;31(20):153-60. [DOI:10.1016/j.clinmic news.2009.09.004]

29. Ghasemian A, Peerayeh SN, Bakhshi B, Mirzaee M. Accessory gene regulator specificity groups among Staphylococcus aureus isolated from hospitalized children. Archives of Pediatric Infectious Diseases. 2014;2(4). [DOI:10.5812/pedinfect.16096]

30. Parhizgari N, Khoramrooz SS, Hosseini M, Asghar SA, Marashifard M, Yazdanpanah M, et al. High frequency of multidrug-resistant Staphylococcus aureus with SCCmec type III and Spa types t037 and t631 isolated from burn patients in southwest of Iran. Apmis. 2016;124(3):221-8. [DOI:10.1111 lapm.12493] [PMID]

31. Montazeri EA, Khosravi AD, Jolodar A, Ghaderpanah M, Azarpira S. Identification of methicillin-resistant Staphylococcus aureus (MRSA) strains isolated from burn patients by multiplex PCR. Burns. 2015;41(3):590-4. [DOI:10.1016/j.burns.2014.08.018] [PMID]

32. Abbasi-Montazeri E, Khosravi AD, Feizabadi MM, Goodarzi $\mathrm{H}$, Khoramrooz SS, Mirzaii M, et al. The prevalence of methicillin resistant Staphylococcus aureus (MRSA) isolates with high-level mupirocin resistance from patients and personnel in a burn center. Burns. 2013;39(4):650-4. [DOI:10.1016/j.burns.2013.02.005] [PMID]

33. Namvar AE, Afshar M, Asghari B, Lari AR. Characterisation of SCCmec elements in methicillin-resistant Staphylococcus aureus isolated from burn patients. Burns. 2014;40(4):708-12. [DOI:10.1016/j.burns.2013.09.010] [PMID]

34. Rodrigues MVP, Fortaleza CMCB, Riboli DFM, Rocha RS, Rocha C, de Souza MdLR. Molecular epidemiology of methicillin-resistant Staphylococcus aureus in a burn unit from Brazil. Burns. 2013;39(6):1242-9. [DOI:10.1016/j.burns .2013.02.006] [PMID] 